KINDLER OF SOULS 
Focus on American History Series

Center for American History University of Texas at Austin

Edited by Don Carleton 


\section{KINDLER OF SOULS}

Rabbi Henry Coben of Texas

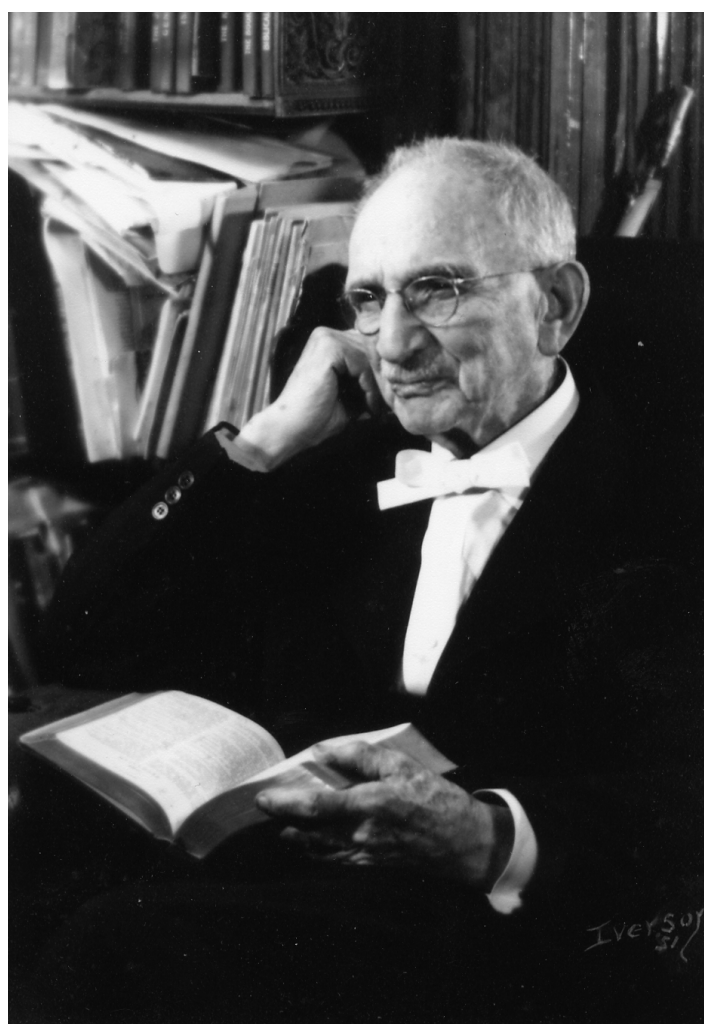

by Rabbi Henry Cohen II

UNIVERSITY OF TEXAS PRESS 
Copyright (C) 2007 by the UNIVERSITY OF TEXAS PRESS

All rights reserved

Printed in the United States of America

First edition, 2007

Requests for permission to reproduce material

from this work should be sent to:

Permissions

University of Texas Press

P.O. Box 7819

Austin, TX 78713-7819

www.utexas.edu/utpress/about/bpermission.html

The paper used in this book meets the minimum requirements of ANSI/NISO Z39.48-I992 (RI 997) (Permanence of Paper).

\section{Library of Congress Cataloging-in-Publication Data}

Cohen, Henry, I927-

Kindler of souls : Rabbi Henry Cohen of Texas / Rabbi Henry Cohen II. - Ist ed.

p. cm. - (Focus on American history series)

Includes bibliographical references and index.

ISBN-I 3: 978-0-292-7I46I-8 (cloth : alk. paper)

ISBN-IO: 0-292-7I46I-O (cloth : alk. paper)

I. Cohen, Henry, I863-I952. 2. Rabbis-Texas-Galveston-Biography.

3. Reform Judaism-Texas-Galveston. 4. Galveston (Tex.) - Social conditions.

5. Galveston (Tex.) - Biography. I. Cohen, Henry, I 927 - Poems. Selections.

II. Title. III. Series.

вм755.c6с64 2007

$296.8^{\prime} 341092-\mathrm{DC} 22$

[B]

2006017295 
To the great-grandchildren of Rabbi Henry Cohen Henry and Ruth, Shelley and Lisa 